\title{
Study of Customer Loyalty in Small and Medium-Sized Enterprises in the Field of Trade in Bulgaria
}

\author{
Vyara Kyurova ${ }^{1}$, and Blagovesta Koyundzhiyska-Davidkova ${ }^{2, *}$ \\ ${ }^{1}$ South-West University, Faculty of Economics, Department of Management and Marketing, Ivan \\ Mihaylov 60, 2700 Blagoevgrad, Bulgaria \\ ${ }^{2}$ South-West University, Faculty of Economics, Department of Economics, Ivan Mihaylov 60, 2700 \\ Blagoevgrad, Bulgaria
}

\begin{abstract}
.
Research background: In the context of globalization and the increasingly competitive environment, customer loyalty plays an important role in the long-term success of small and medium-sized enterprises. Research by various authors has shown that loyalty is an important customer-oriented marketing tool and is directly dependent on customer satisfaction. Customer loyalty is highly influenced by the quality of the products, the applied price strategy and the good communication between enterprises and customers. Loyalty is the main aim of strategic enterprises marketing planning and is the key to retaining customers. The adoption and application of the loyalty approach in enterprises activity is a prerequisite for increase the trend of customers towards more frequent products consumption and enlarge their desire for more purchases. In connection with solving the problem of customer loyalty, researchers focus on its influencing factors and highlight as most important the following: satisfaction, trust, commitment, customer value and service quality.

Purpose of the article: This report clarifies the peculiarities of customer loyalty and based on an analysis of the factors influencing it brings out the main problems of small and medium-sized enterprises in the field of trade in Bulgaria.

Methods: The sources that were used include a questionnaire survey of 64 enterprises. The analysis and evaluation are based on statistical methods.

Findings \& Value added: The findings include identification of problems, related to the customer loyalty in small and medium-sized enterprises in the field of trade in Bulgaria. The study can be used as a model for analysis of customer loyalty in the trade sector.
\end{abstract}

Keywords: customer loyalty; factors; customer satisfaction; small and medium-sized enterprises (SMEs)

JEL Classification: $M 14 ; L 29 ; F 10$

*Corresponding author: vesi_8808@abv.bg 


\section{Introduction}

Customer loyalty plays an important role in the long-term success of small and mediumsized enterprises in a globalized and fierce competitive environment. In this regard, Cheng, $\mathrm{Wu}$ and Chen emphasize that creating loyal customers is vital for business [1]. Moreover, some authors conclude that the acceleration of global economic integration and fierce business competition have challenged the ways in which customer loyalty is established and maintained [2].

Customer loyalty is important for maintaining the won market share, and in some cases for the long-term survival of the enterprise. This finds support in a study by Kwiatek, Morgan and Thanasi-Boçe, who claim that the importance of customer loyalty on the contemporary marketplace is undeniable [3]. At the same time, loyalty is an important marketing tool that SMEs use to influence the customer. In addition, loyalty is a key goal that companies set for strategic marketing planning. The adoption and application of the loyalty approach in the activity of enterprises in turn helps to increase the propensity of customers to consume the products offered. In addition, customer loyalty provides longterm benefits to businesses in order to maintain their competitiveness [4] and has a significant positive impact on profitability [5]. The task of small and medium-sized enterprise representatives to retain customers is crucial for achieving a sustainable competitive advantage [6]. What's more, customer loyalty is not only the largest asset of any enterprise but it is also an important requirement in its creation [7].

In this context, it is important for different researchers to understand the nature of customer loyalty. Sundström and Hjelm-Lidholm consider loyalty from a conceptual point of view. According to them, it is a complex concept based on devotion, trust, subservience, social relations and mutual dependence [8]. Some authors emphasize that customer loyalty is a complex concept that involves two dimensions: instrumental (repurchase intention) and expressive (advocacy intention) [9]. Additionally, Bass views loyalty as a tendency to repeated purchases [10]. Jacoby and Chestnut's view is different, as they relate loyalty to a set of customer preferences and beliefs that can be combined with the concept of "cognitive loyalty" [11]. A relatively more comprehensive definition of customer loyalty is given by Linina and Zvirgzdina. According to them, loyalty is the result of the customer perception of the offer (product, service, brand, etc.), leading to a positive attitude (cognitive, trustful and emotional) and a favorable attitude towards the company (repeated purchases, additional purchases, high consumption intensity, etc.) [12]. On the other hand, cognitive loyalty is directly related to implicit and explicit communication and intercultural dialogue when interacting with customers [13].

In clarifying the nature of customer loyalty, some authors use as a starting point the perception of the brand. Specifically, the position of McMullan and Gilmore is that customer loyalty should be considered as partiality for a brand and behavioral reaction over time, whereby an individual desires a specific brand over other brands [14]. In their view, some authors associate loyalty with the highest acceptance level of a brand by customers and emphasize that this is usually evident from the customers' buying behavior [15]. Moreover, Kliestikova et al. [16] claim that the national socio-cultural profile affect the priority of the components on the brand value source, the importance of corporate social responsibility activites and its impact on brand value is depicted in the study of Kadekova et al. [17].

The research interest, expressed in the above studies by various authors in contemporary conditions shows the ever-growing interest in customer loyalty as a phenomenon of great importance for the development of entrepreneurial business. In this respect, it should be 
noted that customer loyalty, in our opinion, is a customer concept based on a synthesis of customers' perception of the product offered by the company; their purchase behavior; their positive attitude towards the brand and the company and their desire to purchase again.

For the development of a justifiable and adequate to market conditions marketing policy, it is important for the entrepreneurial business to know the behavioral characteristics of its loyal customers. In this vein, some authors consider the following main characteristics of the behavior of loyal customers on the market as inherent: they buy more and stay loyal for longer; they are less sensitive to price increases; they recommend other customers to buy and use a particular product [12]. The same authors define the above characteristics in view of aspects, such as: word-of-mouth communication costs nothing; recommendations contain specific information based on consumption; communication comes from friends or acquaintances you can trust [12]. To these characteristics, based on the level of loyalty, they add the following: calls for lower customer acquisition costs; the development of a solid customer database; possibility to increase product/ brand prices within certain limits; promotions of product sales and profit growth; opportunities for a positive corporate image and reputation [18].

A good knowledge of the factors influencing it is important for creating customer loyalty. At the same time, the analysis and evaluation of these factors contributes to achieving greater customer confidence, increasing competitiveness and providing significant competitive advantages to the company [12]. However, there is no consensus in the scientific literature on the factors that shape customer loyalty. A certain group of authors $[19,20,21,4,22,23]$ identify brand image, brand trust, brand affect and customer satisfaction as the most important factors contributing to increasing customer loyalty. According to Rauyruen and Miller, the most significant factors shaping customer loyalty include service quality, customer value, trust and commitment [24]. The factors that shape customer loyalty, proposed by Rai and Medha are also of interest, e.g. service quality, customer satisfaction, trust, commitment, corporate image, switching costs and communication [25]. The degree of satisfaction depends much more on customers' needs, expectations and experience and is in fact a category of perception where service quality can be directly measured and observed [26]. Certain authors consider the factors, influencing customer loyalty in three aspectual dimensions: loyalty affecting factors in relation to the company, its products or services (quality, product/ service price, customer loyalty programs); loyalty influencing factors in conjunction with the development of relations (relationship quality of previous experience, confidence); loyalty influencing factors in conjunction with buyers' characteristics [27]. In this regard, V. Krastev identifies the conflict of interest as a key element influencing customer loyalty in terms of enterprises, its products or services [28]. Vilkaite-Vaitone and Skackauskiene have a more comprehensive view on the issue of the factors influencing customer loyalty. They classify them into the following three groups: customer factors (age, gender, income, socioeconomic status, switching costs); service provider factors (quality, price, working hours, service life-cycle, service culture, reputation, location, marketing, assortment, innovativeness, payment options, supporting services, personnel qualifications, service personalization, service provider environment); environment factors (competitiveness, economic well-being, social support) [7].

In our opinion, each of the above factors influencing customer loyalty plays an important role in its development. It is obvious that the knowledge, analysis and evaluation of the factors influencing customer loyalty is highly important for the implementation of the business activity, related to the retention of the loyal customers and the attraction of new ones. Along these lines, the establishment of the strength of the impact of these factors, the relationship between them, the conditions formed by their manifestation and the 
different ways of combining them helps to determine the behavior of the businesses in relation to loyal customers.

\section{Research methodology}

This study has used primary data. The survey is carried out on a sample of representative character. The assessment of customer loyalty in small and medium-sized enterprises in the field of trade in Bulgaria is based on the results of a survey conducted among 64 business representatives through the method of respondents. The main reason for choosing this method is its adequacy in terms of the specifics of the subjects and the data to be obtained. In addition, the method of respondents is appropriate in terms of field work with respondents due to the fact that it helps to obtain direct access to the respondents through personal and group meetings. The survey was conducted in the period March-May 2020 .

Statistical methods have been used to analyze and evaluate the results obtained from the study, such as observation method, grouping method, analysis method, graphical and tabular method.

The implementation of a questionnaire as a research instrument feeds in and enables the collection and analysis of quantative data, using descriptive statistics. Data have been collected from the surveyed enterprises by means of a designed-by-the-authors questionnaire, due to the fact that it corresponds to a high degree to the goals set for the current research.

\section{Results - Assessment of customer loyalty in small and medium-sized enterprises in the field of trade}

In connection with a more comprehensive and accurate discussion of the problem, we believe that it is necessary to outline the profile of entrepreneurial business. The results of the business analysis according to the form of registration reveal that most significant is the share of sole proprietorships with limited liability (67.5\%), followed by Ltds $(25.7 \%)$ and sole traders $(6.8 \%)$.

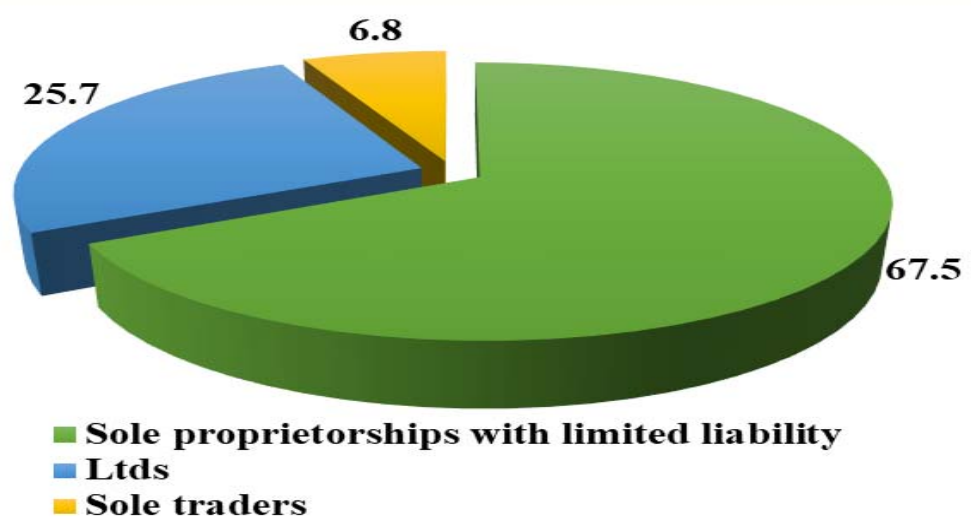

Fig. 1. Distribution of enterprises according to the form of registration.

Source: authors' own research

The structure of the researched businesses can also be considered in terms of their size. The data in Figure 2 show that micro-enterprises predominate with a share of $63.8 \%$. The 
share of small enterprises is significantly smaller $-24.6 \%$, followed by the representatives of medium-sized enterprises, whose share is $10.2 \%$. Only $1.4 \%$ of the respondents indicate that they are representatives of large enterprises.

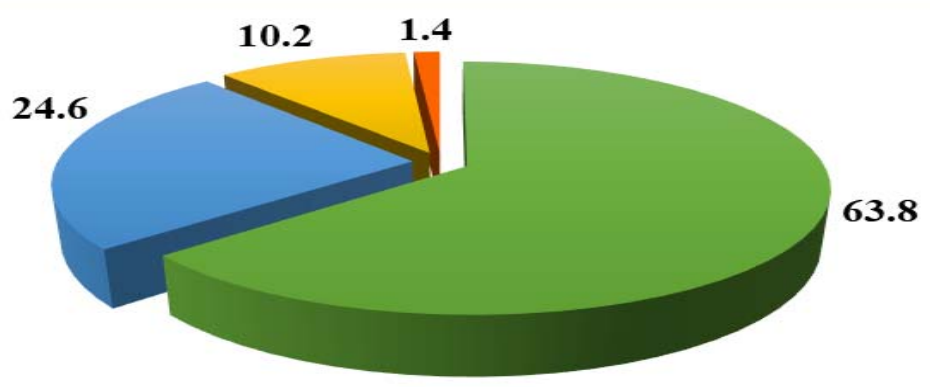

\section{Micro-enterprises \\ - Small enterprises \\ Medium-sized enterprises $\square$ Large enterprises}

Fig. 2. Distribution of enterprises by size.

Source: authors' own research

Of particular importance for the effective management of entrepreneurial business is the study of the factors influencing customer loyalty. In this context, the results of the survey show that more than a third of the respondents are fully convinced that the study of these factors is a prerequisite for the optimal implementation of tasks related to business management. It has been found that the share of business representatives who believe that this type of research is a prerequisite for success predominates over the rest (66.7\%).

As already mentioned, it is especially important for the entrepreneurial business to identify the factors that shape customer loyalty. In this regard, the results of the study presented in Table 1 show that all respondents identify the following factors as the most important: "communication/dialogue with the client"; "excellent product quality that does not change over time"; "the price corresponds to the quality of the product"; "quality of service" and "customer satisfaction". As a determining factor for customer loyalty, a significant share of the representatives of entrepreneurial business point out "the offered range of products/services" (66.7\%).

Table1. Factors for shaping customer loyalty.

\begin{tabular}{|c|c|}
\hline Factors & Share, $\mathbf{\%}$ \\
\hline Communication/dialogue with the client & 100.0 \\
\hline Excellent product quality that does not change over time & 100.0 \\
\hline The price corresponds to the quality of the product & 100.0 \\
\hline Quality of service & 100.0 \\
\hline Customer satisfaction & 100.0 \\
\hline Offered range of products/services & 66.7 \\
\hline Commitment to the client & 51.3 \\
\hline Desire to buy the product again & 42.7 \\
\hline Acceptable payment terms & 28.6 \\
\hline Trust in the company & 21.8 \\
\hline Well-packaged product & 15.2 \\
\hline
\end{tabular}

Source: authors' own research 
Note: The total number of percentages exceeds $100 \%$, as it was possible to give more than one answer

Of interest are the factors related to the quality of service, identified as the most important by the entrepreneurial business. The data presented in Table 2 reveal that the most important factors related to the quality of service are "competence of the staff", "willingness to quickly fulfill customer requests" and "quality products". There is also a significant share of respondents who believe that "confidentiality to the customer" $(92.3 \%)$, "convenient location of the commercial site" (89.7\%) and "professional appearance of staff" $(80.8 \%)$ are also major factors, directly related to the quality of service.

Table 2. Factors related to the quality of service.

\begin{tabular}{|c|c|}
\hline Factors & Share, $\mathbf{\%}$ \\
\hline Competence of the staff & 100.0 \\
\hline Willingness to quickly fulfill customer requests & 100.0 \\
\hline Quality products & 100.0 \\
\hline Confidentiality to the customer & 92.3 \\
\hline Convenient location of the commercial site & 89.7 \\
\hline Professional appearance of the staff & 80.8 \\
\hline Reasonable price & 66.7 \\
\hline Sufficient range of products & 33.3 \\
\hline
\end{tabular}

Source: authors' own research

Note: The total number of percentages exceeds $100 \%$, as it was possible to give more than one answer

Regarding the factors related to the trust in the enterprise, the results of the survey presented in Table 3 show that the most important factor is "honesty to the customer". It is noteworthy that according to $93.7 \%$ of the respondents, the well-trained staff contributes to the creation of customers' trust in the enterprise. For a significant share of respondents (78.9\%), the main factor influencing the trust in the company is the fact that it provides the best alternative to the product sought by the customer.

Table 3. Factors related to the trust in the enterprise.

\begin{tabular}{|c|c|}
\hline Factors & Share, $\mathbf{\%}$ \\
\hline Honesty to the customer & 100.0 \\
\hline Well-trained staff & 93.7 \\
\hline The enterprise provides the best alternative to the product sought by the customer & 78.9 \\
\hline Giving appropriate advice in critical moments & 33.3 \\
\hline
\end{tabular}

Source: authors' own research

Note: The total number of percentages exceeds $100 \%$, as it was possible to give more than one answer

In connection with the commitment of the representatives of the entrepreneurial business to their customers, it is established that the most important factor is the repeated purchases and recommendations from the customer $(98.6 \%)$, followed by the strong sense of belonging of the customer $(72.5 \%)$.

With respect to the determining factors related to "enterprise-customer" communication (q.v. Figure 3), the respondents indicate that the best communication between the enterprise and the customer is most significant (61.9\%). According to them, timely and reliable information from the company (25.4\%) and good communication between customer and supplier of products are also important (12.7\%). 


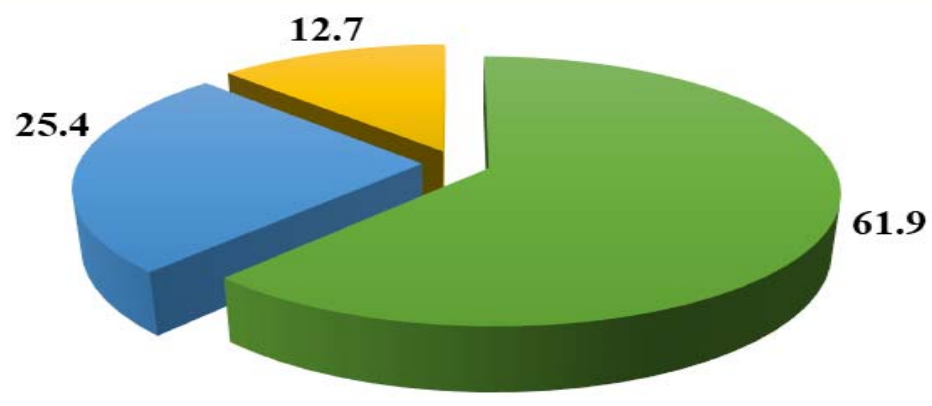

\section{The best communication between the enterprise and the customer \\ Timely and reliable information from the company \\ Good communication between customer and supplier of products}

Fig.3. Factors related to enterprise-customer communication.

Source: authors' own research

It is especially important for the entrepreneurial business to find an approach to retain their customers and fully satisfy their ever-increasing requirements. In this respect, it is necessary to identify the factors associated with increasing customer loyalty. The data in Table 4 reveal that the quality of service is the determining factor related to increasing customer loyalty, according to all respondents. In addition, they define "brand trust" $(69.2 \%)$ and "customer satisfaction" $(58.4 \%)$ as significant factors. As the least influential factor, the respondents indicate "brand image" (41.6\%).

Table 4. Factors related to increasing customer loyalty.

\begin{tabular}{|c|c|}
\hline Factors & Share, $\%$ \\
\hline Quality of service & 100.0 \\
\hline Brand trust & 69.2 \\
\hline Customer satisfaction & 58.4 \\
\hline Brand image & 41.6 \\
\hline
\end{tabular}

Source: authors' own research

Note: The total number of percentages exceeds $100 \%$, as it was possible to give more than one answer

The development of a customer loyalty programs will contribute to successful and effective communication between the company and customers. It will be of great benefit to have such programs created and practically applicable by the representatives of the entrepreneurial business. Unfortunately, it was found out that a very small part of the respondents had developed a customer loyalty program $(18.5 \%)$. On the positive side, they all intend to create such programs.

\section{Conclusion}

Theory proves that customer loyalty is important for achieving long-term success and increasing the competitiveness of any enterprise. Customer loyalty is one of the main tools for influencing current customers of the products/ services offered by the enterprise. It is established that the basis for the development of a proper marketing policy of the 
entrepreneurial business is the clarification and analysis of the behavioral characteristics of its loyal customers. Knowledge of the factors influencing their behavior to varying degrees is important for making the right management decisions regarding loyal customers.

Practice shows that a small number of representatives of small and medium-sized enterprises in the field of trade have developed an effective customer loyalty program which is indicative of the lack of sufficient targeted action in relation to loyal customers. The results obtained from the current research reveal that some of the respondents do not pay enough attention to the analysis of the factors influencing customer loyalty. It is obvious that they do not sufficiently understand yet the importance of studying these factors for the effective management of their business. It is necessary to take into account such important factors that shape customer loyalty as the prestige and status of the company, competition in price with that of other similar products/ services, and product catalogs containing detailed and easy-to-understand information. It is important when analyzing the factors related to the quality of service to take into account the positive impression of the atmosphere of the store site. In connection with the successful implementation of the activities related to customer engagement, it is recommended that the representatives of small and medium enterprises in the field of trade provide greater benefits than their competitors and make the products offered very valuable to their customers. Despite the intensified processes of globalization and digitalization, "face-toface" communication is a key factor in the implementation of effective "enterprisecustomer" communication, that is why it is imperative for enterprises to take into account its impact.

In conclusion, in our opinion, it is necessary for the representatives of small and medium enterprises in the field of trade to focus their efforts on the complex combination and analysis of the influence of factors related to customer loyalty which will ensure proper management decisions regarding communication and communication with loyal customers.

\section{References}

1. Cheng, F.-F., Wu, C.-S., Chen, Y.-C. (2020). Creating customer loyalty in online brand communities. Computers in Human Behavior, 107(4).

2. Huang, L., Wang, M., Chen, Z., Deng, B., Huang, W. (2020). Brand image and customer loyalty: Transmitting roles of cognitive and affective brand trust. Social Behavior and Personality: An International Journal, 48(5), e9069.

3. Kwiatek, P., Morgan, Z., Thanasi-Boçe, M. (2020). The role of relationship quality and loyalty programs in building customer loyalty. Journal of Business \& Industrial Marketing.

4. Fernandes, T., Moreira, M. (2019). Consumer brand engagement, satisfaction and brand loyalty: A comparative study between functional and emotional brand relationships. Journal of Product \& Brand Management, 28(2), 274-286.

5. Haghkhah, A., Rasoolimanesh, S. M., Asgari, A. A. (2020). Effects of customer value and service quality on customer loyalty: mediation role of trust and commitment in business-to-business context. Management Research and Practice, 12(1), 27.

6. Eakuru, N., Mat, N. (2008). The application of structural equation modeling (SEM) in determining the antecedents of customer loyalty in banks in South Thailand. The Business Review, Cambridge, 10(2), 129-139.

7. Vilkaite-Vaitone, N., Skackauskiene, I. (2020). Service customer loyalty: An evaluation based on loyalty factors. Sustainability, 12, 2260. 
8. Sundström, M., Hjelm-Lidholm, S. (2020). Re-positioning customer loyalty in a fastmoving consumer goods market. Australasian Marketing Journal, 28, 33.

9. Chai, J. C. Y., Malhotra, N. K., Alpert, F. (2015). A two-dimensional model of trustvalue-loyalty in service relationships. Journal of Retailing and Consumer Services, 26, 23-31.

10. Bass, F.M. (1997). The theory of stochastic preference and brand switching. Journal of Marketing Research, 11, 1-20.

11. Jacoby, J., Chestnut, R. (1978). Brand loyality measurement and management. New York, Willey

12. Linina, I., Zvirgzdina, R. (2020). Evaluation of buyer's loyalty process in retailcompanies in Latvia under the conditions of globalization. Proceedings of the $19^{\text {th }}$ International Scientific Conference Globalization and its Socio-Economic Consequences (pp. 04013), 74. University of Zilina: Zilina.

13. Kiryakova-Dineva, T., Hadzhipetrova-Lachova, M., Chankova, Y. (2017). Intercultural dialogue for education in the mediterranean region. Proceedings of the $9^{\text {th }}$ International Conference on Educationa dn New Learning Technologies Edulearn17 (pp. 39203926). Barcelona.

14. McMullan, R., Gilmore, A. (2008). Customer loyalty: An empirical study. European Journal of Marketing, 42(9/10).

15. Othman, B. A., Harun, A., De Almeida, N. M., Sadq, Z. M. (2020). The eff ects on customer satisfaction and customer loyalty by integrating marketing communication and after sale service into the traditional marketing mix model of Umrah travel services in Malaysia. Journal of Islamic Marketing.

16. Kliestikova, J., Durana, P., Kovacova, M. (2019). Naked Consumer's mind under branded dress. Case study of Slovak Republic. Central European Business Review, 8(1), 15-32.

17. Kadekova, Z., Savov, R., Kosiciarova, I., Valaskova, K. (2020). CSR activities and their impact on brand value in food enterprises in Slovakia based on foreign participation. Sustainability, 12(12), 4856.

18. Linina, I., Zvirgzdina, R. (2016). The consumer loyality formatiom process and its particularities in the retail sector, Vilnius.

19. Ahmed, Z., Rizwan, M., Ahmad, M., Haq, M. (2014). Effect of brand trust and customer satisfaction on brand loyalty in Bahawalpur. Journal of Sociological Research, 5, 306-326.

20. Alhaddad, A. (2015). A structural model of the relationships between brand image, brand trust and brand loyalty. International Journal of Management Research \& Review, 5, 137-144.

21. Anwar, A., Gulzar, A., Sohail, F. B., Akram, S. N. (2011). Impact of brand image, trust and affect on consumer brand extension attitude: The mediating role of brand loyalty. International Journal of Economics and Management Sciences, 1, 73-79.

22. Khamitov, M., Wang, X., Thomson, M. (2019). How well do consumer-brand relationships drive customer brand loyalty? Generalizations from a meta-analysis of brand relationship elasticities. Journal of Consumer Research, 46, 435-459.

23. Lin, C.T.L., Chuang, S.S. (2018). The importance of brand image on consumer purchase attitude: A case study of e-commerce in Taiwan. Studies in Business and Economics, 13, 91-104. 
24. Rauyruen, P., Miller, K. E. (2007). Relationship quality as a predictor of B2B customer loyalty. Journal of Business Research, 60(1), 21-31.

25. Rai, A. K., Medha, S. (2013). The antecedents of customer loyalty: An empirical investigation in life insurance context. Journal of Competitiveness, 5(2), 146.

26. Vasenska, I., (2018). Global creative economic interpretations of the Valley of the Thracian kings on the example of Starosel, Bulgaria. Proceedings of the $18^{\text {th }}$ International Scientific Conference Globalization and Its Socio-economic Consequences. University of Zilina: Zilina.

27. Isoraite, M. (2016). Customer loyalty theoretical aspects. Ecoforum, 5, 2(9), 298.

28. Krastev, V. (2015). The conflict of interests in the private sector. Researches on economic history and history of the social-economic sphere in Southwestern Bulgaria. SWU ,Neofit Rilski “. 317-327. 